\title{
THE IMPACT ON THE DEVELOPMENT OF THE TAPPED FURNITURE ON THE DESIGN AND THE MATERIALS OF THE MODERN FURNITURE
}

\author{
Petar Namicev, ${ }^{1}$ Tatjana Doneva ${ }^{2}$ \\ ${ }^{1,2}$ University Goce Delcev Shtip, Republic of Macedonia \\ petar.namicev@ugd.edu.mk, tatjana_7doneva@hotmail.com
}

\section{Original Scientific Paper doi:10.5937/jouproman7-19997}

\begin{abstract}
The design of furniture in the Middle Ages as a work of art made by top artists creates a great application in the development of a growing number of small pieces of furniture.

The design of 15th-century stools, which was governed by nature, and the need for durable, simple and functional shapes, are also today widely used. Today, more homes use upholstery as a kind of decoration and durability. Today's modern furniture, such as furniture design from the 20th century, carries certain features, with simpler shapes and a richer selection of materials and with much simpler decoration.

Based on the detailed analysis of the characteristics, as well as their comparison, we can see the connection between them.
\end{abstract}

Keywords: chair, shape, design, color, material, upholstery, furniture.

\section{Introduction:}

In the wood industry, upholstery as a branch is an important activity in the economy. That branch existed as industrial production and as a craft throughout history and earlier. The editing and design that are present in the homes are of different shapes and designs. His significance is marked with increased comfort in the life of a man at his home. In the 20th century, synthetic cotton was used as the last coating layer. For cladding, different fabrics are used (canvas with a wide range of models, velvet, monochrome, plush, monochrome, colorful,), and was most often used natural leather with the highest quality or shine. Furniture in the 20th century needs to satisfy the needs of modern housing. The furniture (chair) should be practical, convenient, has a multiple purpose and allow maximum utilization of the interior space. Modern design is distinguished by various forms and application of materials. Its main feature that distinguishes the design is making lines, minimalist forms, practicality and easy fit in space. (Trajkovska 2013).

The development of carpentry is undergoing major changes, initially, from a primitive way, through craft, to an industrial semi-automated and automated way in the production of wallpaper products. (Ivetic 1989 ).

\section{The development of furniture in the Middle Ages}

The Middle Ages marks the period from the 5th to the 15th century, when the furniture began to develop its modern characteristic. One of the important stages in the production of upholstered furniture (chairs) is the construction of the supporting structure. Oak tree, walnut and pine are the material from which the carrying structure of the chairs was most often made, was most accessible. Later with the development of people's culture, furniture began to be made of exotic wood species such as cedar and ebony that were procured from the eastern countries. During the making of furniture, the metal was used for making hinges, various decorations and artistic handles made of gilded iron. As a decorative material, fabrics in the Middle Ages were used for door trims, curtains around beds, and pillows.

The furniture used in the living quarters was composed of a chair with handles and a high backrest, or a folding chair $\mathrm{X}$, a cupboard, a bench, a bed with columns, a coffin, a mirror and other smaller pieces of furniture. 
One of the most important pieces of furniture was the coffin, which was made of hollow stems used for packaging domestic property and seat, table or sofa to sleep. (Ivetic 1989 ).

\section{Development of upholstered furniture}

Historical development of the chairs began in ancient Egypt. Originated from the Third Dynasty of the ancient Egyptians (2650-2575 BC). The chairs were considered as a great treasure in the historical development of the interior. Materials from which they were made are ebony and ivory, or from carved and gilded wood.

The chairs were covered with rich materials that had a characteristic design of the legs (various figures, most often legs of the beast). The people believed that the chairs should be made in a simple and natural form. The seats on the chairs were covered with leather or velvet, and in the homes of the rich people were used armchairs that were betting with embroidered fabric, additional pillows, rings and buttons. In the rich families for the host, a high-back chair was made, which was richly decorated with relief, called the throne. (Karadžić 1972).

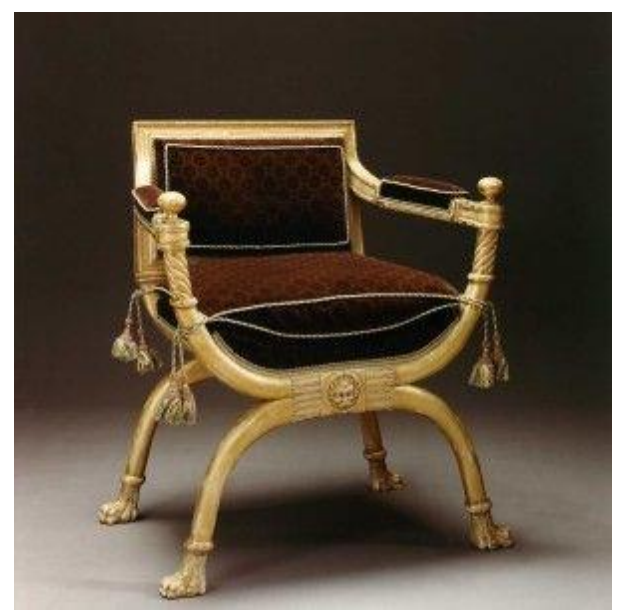

Fig.1.Egyptian chair

In the 15th century, a new type of capital of collection was developed, on the chair the folding so called Falsteria or Savonarola chair. The chair was made of walnut tree, which had folding legs and was decorated with carvings and plating. For comfort of the seat was covered with velvet or leather, and additional pillows for decoration were used. Until the 19th century, more attention was paid to the design of the chair than to comfort and functionality. The chairs were usually made exclusively of wood (Mursell 2009).

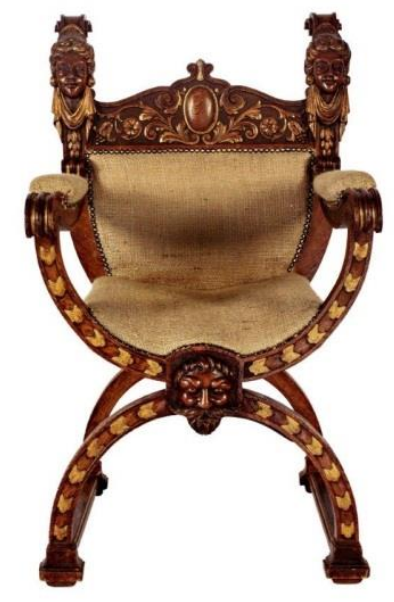

Fig.2.Savonarola chair

\section{The development of the tapestry}

The upholstery appeared in the 18th century, as a separate independent profession, much later than other professions and crafts. At the beginning, upholstery was made only by saddles, craftsmen, purse.

In Berlin in 1824, the first union of wallpaper was upholstery, and in 1846 it appeared officially of the upholstery profession appeared, thus creating a new profession called a wallpaper decorator. (Bast 1946).

It is important as far as possible to better manage a single living space, which will enable the man a better and more comfortable life in it. The upholstery in its development has experienced many changes from craft to full industrial (Manevska, Andonova, 2013). 


\section{Analysis of material selection}

Nowadays special attention is paid to the materials used for the production of upholstered furniture, particularly important are the charges (fillers) and the materials used for coating. It is important that the upholstered furniture is fully adapted to the health of the people, that is, to satisfy the conditions of use. (Manevska 2013).

The upholstered furniture needs to fulfill several conditions:

- Functionality-representing the products for adjustment and goal for which they are intended, in relation to physiology, anthropometry, hygiene and other sciences;

- Constructive requirements aimed at perfecting the constructions, which are characterized by: rationality, hardness, durability, security in application and high degree of technology;

- technological requirements, are conditioned by the state of the technological process of the producer and the type of production;

- technological-economic which conditional economy of the product, technical conditions of control, storage, equipment, etc .;

- aesthetic requirements, which condition the unity between aesthetic and functional characteristics (Stefanovski 1994).

The material used for betting on upholstered products can be divided into two groups:

- fabrics for making the substrate and pillows;

- coating fabrics - furniture items.
In the layer of fine charge for the upholstered chairs, fiber crops such as cotton, hemp, flax, sea grass, and materials of animal origin are used: wool, feathers, horsehair, silk and others.

In the layer of furniture-fabrics that are used with a smooth surface are the damask, tapestry, brocade, mattress and others. Ribbed furniturefabrics are epling, ripe, and others. Velor-fabrics are venetian suede, frieze, and others.

Natural leather is considered one of the oldest, elegant and precious materials.

The quality of the skin depends on the technology and the raw materials used in the processing process, type, age, race, and skin damage. ( Grbac, Ivelic 2005).

In today's special attention is paid to the materials used for the production of upholstered chairs, especially the filling and coating materials, which meets the conditions for use.

\section{Furniture from the 20th century}

Furniture has been perfected from many different aspects - functionality, application of new materials, color, practicality, technique and technology of performance and design. Any time or epoch has its own landmark in both art and furniture and interior.

Significantly bigger attention in the 20th century was paid to the technology of workmanship and the construction of the chairs. In that period, metal folding chairs and plastic chairs were made. and chairs with metal legs.

In addition to the functionality and dimensions, great attention was paid to the aesthetics and design of the chairs.

In the following article we will look at several designs of chairs that are characteristic in the 20th century:

Depending on the type of furniture fabrics, are divided into: smooth, ribbed and suedefabrics. 


\subsection{Barcelona chair}

The most famous Barcelona chair (Figure 3) has gained great popularity that most corporate buildings in the world are unthinkable without it. However, the history of the stool is much richer. The creators who designed the chair are the architect Miss Van Der Roeh and the designer of the interior Lily Reich. It was designed specifically for the German pavilion at the exhibition in Barcelona in 1929, after which it received the name of Barcelona's capital. (Sidorenko 2010).

It is made of reflective chrome with ivorycolored skin, low, wide, slightly bent and modern.

The seat and backrest are filled with foam, while the leather pillows provide strong support and comfort, and the folded, cylindrical metal legs polished to high gloss provide a contrast to the skin of the armchair.

Barcelona chair is characteristic in terms of formality, luxury and simplicity (Sofia Sidorenko 2010).

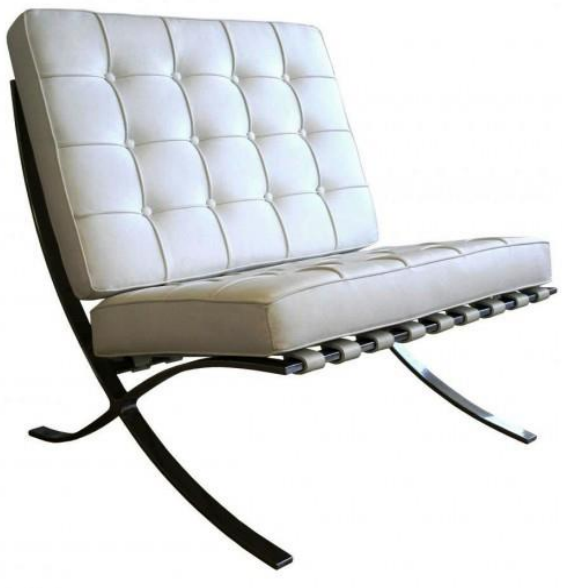

Figure.3. "Barcelona's chair" - Van der Roy and Lily Reich

\subsection{Diamonds are eternal}

"A chair made of air" (Figure 4) got the name that guarantees that it will not get out of fashion. "Diamond" chair was designed and created by Harry Burtoni. She is the carrier of development company Kroll's. She has experienced a great incredible commercial success, and immediately after Bertoi's chair, she fully devoted himself to creating sculptures. (Bertoi 2003).

The diamond chair with a shape and structure of metal bars makes it one of the most famous designs in the middle of the 20th century.

The frame of the chair, which is made of steel construction made of chrome, extending through the seat made of wire, attached to the basket of the seat. Small diamond chair that can be made of polished or satin chrome, in black or white, and fully upholstered seat.

Its popularity, which is not difficult to understand, is beautiful, comfortable, suitable for interiors and exteriors in almost all types of spaces.

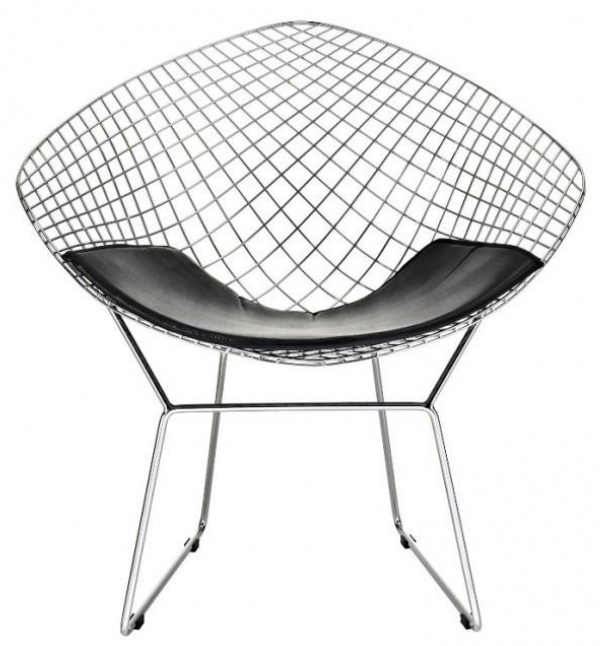

Fig.4. "Diamond" by Hari Bertoi 


\subsection{Stylish Scandinavian chair with an ideal proportion}

Magnus Scogsfjord, who presented an elegant design of the chair named "Stylish Scandinavian Chair". The designer decided to use the triangular and diamond shapes for the parts in his hands, in order to slightly extend the back of the chair. Lines and dimensions as inspiration of diamonds, after which the chair was named Adamantem, which in Latin means a diamond.

(Englund 2015).

The result of the chair is the beauty of complex and coherent designs, with different elements each of which tells another story, which meets as one. Through the backrest, from which it forms the legs of the hands, the shape of this model is contrasted in the form of defining lines. For preparation used a European oak and dark gray wool for the backing of the back seat was used for making, creating a chair which is a very nice seating option for the original Scandinavian and Japanese style.

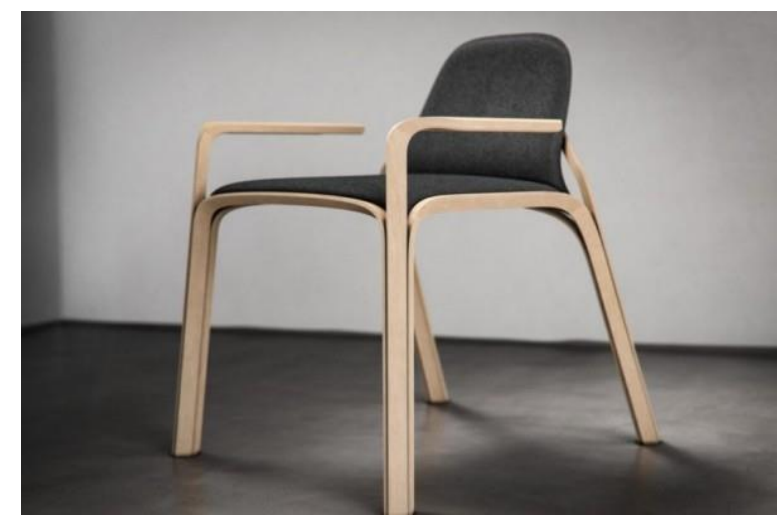

Fig.5. Stylish Scandinavian chair

\subsection{Sarinen chair}

The Sarinen chair which was designed by Ero Saarinen in 1948. Ero, who designed the pioneer chair at the request of Florence Knol for a chair that looked like a basket full of pillows. (Saarinen 2013). The design was supported in any position and provided a comforting sense of security, from where the name came from. This type of chair is a $85 \%$ reduced version perfect for a smaller space or face. The cavity on the seat was made of fiberglass. The base was made of tubular steel with polished chrome or black oil. Designed with great durability, an air quality certificate located in the interior. It is upholstered with a wide range of textiles and skins in different colors.

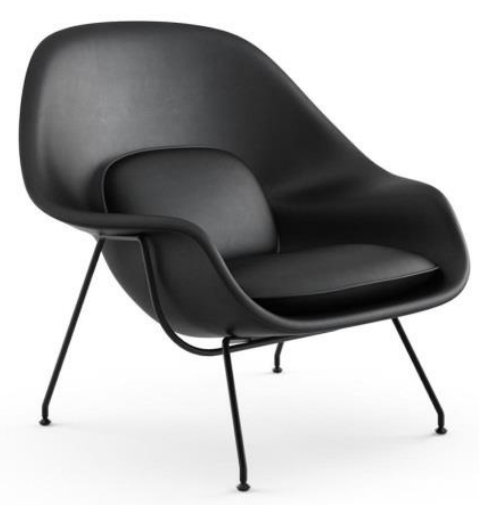

Fig.6. Sarinen chair made of leather

\section{Analysis of the modern design of chairs from the 20th century}

One of the main features of the chairs in the period between (2650-2575 BC) .It was inspired and made of ivory, animal head, rich carving and gold-plated. The use of natural and classical elements used on the chairs in the interior interior is characteristic of the design for the creation of modern chair that are white to the style itself. 
Table 1. Features of 20th century furniture according to shape, material and color

\begin{tabular}{|c|c|c|c|c|}
\hline & Furniture: & Materials: & Form: & Color: \\
\hline $\begin{array}{l}\text { Barcelona } \\
\text { chair }\end{array}$ & Chair & $\begin{array}{l}\text {-reflecting chrome; } \\
\text { - leather; }\end{array}$ & $\begin{array}{l}\text { - a rectangular } \\
\text { shape; } \\
\text { - lower; } \\
\text { - wide; }\end{array}$ & $\begin{array}{l}\text {-color of elephant's } \\
\text { bone; }\end{array}$ \\
\hline $\begin{array}{l}\text { Diamond } \\
\text { chair }\end{array}$ & Chair & $\begin{array}{l}\text {-black skin; } \\
\text {-a network of metal } \\
\text { construction; }\end{array}$ & $\begin{array}{l}\text {-diamond form; } \\
\text {-construction of } \\
\text { metal bars; }\end{array}$ & -silver color; \\
\hline $\begin{array}{l}\text { Scandinavian } \\
\text { chair }\end{array}$ & Chair & $\begin{array}{l}\text {-oak; } \\
\text {-wool; }\end{array}$ & $\begin{array}{l}\text {-diamond form; } \\
\text {-triangular form; }\end{array}$ & - dark gray wool; \\
\hline $\begin{array}{l}\text { Sarinen } \\
\text { chair }\end{array}$ & Chair & $\begin{array}{l}\text { - steel, polished chrome; } \\
\text {-black oil, fiberglass; } \\
\text {-textile, skins; } \\
\text { - classical wool, danish } \\
\text { wool; }\end{array}$ & $\begin{array}{l}\text {-ounded lines; } \\
\text {-shape of the basket; }\end{array}$ & $\begin{array}{l}\text { - silver; } \\
\text { - black; } \\
\text {-brown; } \\
\text {-yellow; } \\
\text { - silver or black } \\
\text { frame; }\end{array}$ \\
\hline
\end{tabular}

Table 2. Features of upholstered furniture according to form, materials and color

\begin{tabular}{|c|c|c|c|c|}
\hline & Furniture: & Materials: & Form: & Color: \\
\hline $\begin{array}{l}\text { Egyptian } \\
\text { chair }\end{array}$ & Chair & $\begin{array}{l}\text {-abony wood; } \\
\text {-an elephant's } \\
\text { bone; } \\
\text {-furniture fabric; }\end{array}$ & $\begin{array}{l}\text { - a rectangular } \\
\text { shape; } \\
\text {-legs to the beast; } \\
\text {-legs of animals; }\end{array}$ & $\begin{array}{l}\text {-golden color; } \\
\text { - it's dark brown; } \\
\text { - carving; }\end{array}$ \\
\hline $\begin{array}{l}\text { Savonarola } \\
\text { chair }\end{array}$ & Chair & $\begin{array}{l}\text { - walnut tree; } \\
\text { Кадифе } \\
\text {-skins; } \\
\text {-pillows; }\end{array}$ & -legs in the letter $\mathrm{x}$; & $\begin{array}{l}\text { - carving; } \\
\text { - golden color; }\end{array}$ \\
\hline
\end{tabular}

They are very easily combined into new pieces of furniture, they are elements that emphasize the design of the modern chair and the comfort itself, but not the colors and the details. The analysis of the characteristic elements of 20th century furniture is shown in Table 1, while the features of the upholstered furniture are shown in Table 2.

\section{Similarities and differences}

The development of design furniture (chairs) driven by the nature and the need of durable, simple, functional, yet perfect furniture pieces, find a connection in the design of furniture from the Middle Ages. The design of modern 20th century chairs, which was designed with simple shapes, charging material and coating material, as well as a simple decoration marks the 20th century. 
The similarities and differences that we can define them on the furniture from the Middle Ages as well as the design of furniture from the 20th century through the following elements:

Table. 3. Similarities and differences between the Egyptian chairs and modern chairs

\begin{tabular}{|c|c|c|}
\hline Egyptian chair & Diamond chair & Sarinen chair \\
\hline $\begin{array}{l}\text { Materials : abony wood, an } \\
\text { elephant's bone, furniture fabric, } \\
\text { leather, embroidered material; }\end{array}$ & $\begin{array}{l}\text { Materials: Black skin } \\
\text {-A network of metal construction; }\end{array}$ & $\begin{array}{l}\text { Materials : - Steel, Polished } \\
\text { chrome; } \\
\text {-Black oil, Fiberglass; } \\
\text {-Textile, Skins; } \\
\text { - Classical wool,Danish wool; }\end{array}$ \\
\hline $\begin{array}{l}\text { Form: a rectangular shape, legs to } \\
\text { the beast, legs of animals; }\end{array}$ & $\begin{array}{l}\text { Form: Diamond form } \\
\text {-Construction of metal bars; }\end{array}$ & $\begin{array}{l}\text { Form: ounded lines, shape of the } \\
\text { basket; }\end{array}$ \\
\hline $\begin{array}{l}\text { Color: golden color, it's dark brown, } \\
\text { carving; }\end{array}$ & Color: Silver color; & $\begin{array}{l}\text { Color: silver, black, brown, yellow, } \\
\text { silver or black frame; }\end{array}$ \\
\hline
\end{tabular}

A chair with a high backrest; Beds with columns; Chairs for assembly; Phototypes with embroidered fabric; Chest of hollow Trees storage domestic property; Sofa for sleeping and seating;

As the main characteristic elements that mark the medieval furniture and 20th century furniture, there were high-backed chairs, chairs with wide seat, materials, shape, color and comfort of the chairs.

The main goal is to simplify the way of styling the chairs and to design chairs with simple materials, easy to process and easy to clean and maintain, as well as user comfort. For a simpler understanding of the ratio of the chairs, it is necessary to analyze the similarities and differences between them: (Angelovski, Manevska, 2013).

\section{Impact analysis}

The upholstery that appeared in the 18th century, played a significant role in the upholstery of furniture, but today besides the upholstery is bigger attention is paid to the design, comfort and choice of material.

\subsection{The influence of the upholstered furniture on the design}

In the Middle Ages from the 5th to the 15 th centuries, were made less rarely the upholstered chairs, as they did not have much application and people were less used in their homes.

The upholstered furniture that has a great influence on the furniture design (chair): 
- Depending on the shape and size, it is necessary to choose material the upholstery that fits that chair.

- There are different materials used to fit the chairs both for the seats and for armrests and backrests.

- The choice of material for application, comfort, functionality, elegance and refinement of material that will be used for betting on one chair.

\subsection{Influence on materials}

When selecting material that is of great importance for betting on one chair, it is necessary to carefully study the strength of the material, resistance, wear, flammability, humidity, texture and color that has a major influence on the design of the chair.

- There are many different types of coating materials such as furniture fabrics, eco skins, skys, prints.

- When selecting the material, select the type of material, and the color that is of great importance to the design of the chair.

- The material should be comfortable, esthetic, easy to maintain and clean as well as the choice of color to match the rest of the furniture in the interior.

Combining warm tones of wood with strong, emphasized and eccentric tones of furniture fabrics and eco leather. The calmness and roundness of the classic and the sharp lines and borders of the modern are a combination that can fit everywhere. In the fashion world, returns to what was once modern, but today, it is combined or merged with the sparkling colors of the prints.

\subsection{The influence of upholstered furniture on the design of modern furniture}

As the main element that characterized the furniture in the Middle Ages (5-15 century) were the curved legs that ended with the head of an animal. The application of the simple elements of furniture from the Middle Ages had a great application for making other smaller furniture that was used in the interior, and thus has a great characteristic of the design in that period. The use and combination of various materials in furniture from the Middle Ages and the modern of the 20th century in the interior is a hallmark of the style. The furniture with simple shapes easily mixes the materials with the older, which emphasize the feeling of comfort, functionality, but it does not apply to colors, details and texture.

With a detailed analysis of the furniture of medieval and furniture of 20th century and their elements and materials, we can conclude that in today's modern furniture there are fewer elements of the features of medieval elements and materials with different colors and patterns, in relation to the specific pieces of furniture, using natural materials, colors, decoration and shapes. 


\begin{tabular}{|c|c|c|}
\hline $\begin{array}{l}\text { Furniture in the } \\
\text { Middle Ages }\end{array}$ & Egyptian chair & $\begin{array}{l}\text { Modern } \\
\text { design }\end{array}$ \\
\hline Furniture & Furniture & Furniture \\
\hline $\begin{array}{l}\text {-chair with handle and high } \\
\text { backrest; } \\
\text { - wardrobe; } \\
\text { - bench; } \\
\text { - bed with poles; } \\
\text {-the coffin; }\end{array}$ & -X-Chair or Savonarola & $\begin{array}{l}\text {-barcelona chair; } \\
\text { - diamond chair; } \\
\text {-scandinavian chair; } \\
\text {-sarinen chair; }\end{array}$ \\
\hline $\begin{array}{l}\text { Materials: } \\
\text { - oak tree } \\
\text { - walnut tree }\end{array}$ & $\begin{array}{l}\text { Materials: } \\
\text { - abony wood, } \\
\text {-an elephant's bone, - } \\
\text { furniture fabric, leather, - } \\
\text { embroidered material; }\end{array}$ & $\begin{array}{l}\text { Materials: } \\
\text { - oak tree } \\
\text {-Челик } \\
\text {-metal }\end{array}$ \\
\hline $\begin{array}{l}\text { Upholstery : } \\
\text {-furniture fabric; } \\
\text { - metal; }\end{array}$ & $\begin{array}{l}\text { Upholstery: } \\
\text { - skins; } \\
\text {-pillows; } \\
\text { - fringed; } \\
\text { - buttons; }\end{array}$ & $\begin{array}{l}\text { Upholstery: } \\
\text { - wool } \\
\text {-textile, } \\
\text {-skins } \\
\text {-fiberlglas }\end{array}$ \\
\hline
\end{tabular}

Table 4. The influence of the upholstered furniture on the design of modern furniture

\section{Conclusion:}

The detailed analysis made on the furniture and its features and elements separately, we can consider the direction in which it moves. The upholstered chairs first appeared in the Middle Ages in Egypt, which in that period made chairs exclusively of wood, gold-plated, rich in carving and were upholstered with a variety of furniture fabrics and rich decoration. (Hills 1993).

The chairs in that period played a significant role because they were betrayed with rich material and decoration, yet they had a simple and natural form.

(Trajkovska 2013).

Upholstered in that period, a very small application for upholstery of different types of furniture, and later in addition to the upholstery there was also decorating with various ornamental materials characteristic for that period in the Middle Ages. The upholstery that has a great presence in today's interior, we can see how it affects the upholstered furniture, the design and materials in modern furniture:
- Use of natural materials, without their additional artificial processing, in order to preserve the natural texture and contours.

- Increased choice of materials in modern furniture, in contrast to the Middle Ages;

- Similarities in the shape and design of furniture with different materials;

- The color and the use of strong and dark colors in the past is richer, while modern furniture prevails with the use of warm and brighter shades.

- The use of decoration, on the stools in the Middle Ages is quite present, while in modern chairs it is almost all the less used;

Based on the complete research, we can conclude that chairs with of the Middle Ages (5th to 15th century) were made with simple and natural forms that are simply defined and made with rounded elements and durable, which are both inspiration and application at different periods for a better and useful development of the design of chairs. 
(JPMNT) Journal of Process Management - New Technologies, International Vol. 6, No 2, 2018.

\section{References:}

1. Manevska, O. Andonova, E.(2013). Finalna obrabotka na drvoto, Ministerstvo za obrazovanie I nauka na R.M, Skopje

2. Trajkovska, S. (2013). Proektiranje na mebel, Ministerstvo za obrazovanie I nauka na R.M, Skopje

3. Angelovski, Z. Manevska, O. (2013). Elementi na drvnite konstrukcii, Ministerstvo za obrazovanie I nauka na R.M, Skopje

4. Ivetic, D.(1989). Tehnologija tapetarske proizvodnje, Zavod za ucebnike I nastavna sreedstva, Zavod za udžbenike,

Beograd,Novi Sad

5. Grbac,I. Ivelic, Ž. (2005). Ojastuceni nameštaj, Sveucilište u Zagrebu, Šumarski fakultet, Zagreb

6. Karadžić,V. (1972). Stilovi, nameštaj $i$ dekor od srednjeg veka do danas, Larousse, Beograd

7. Sidorenko, S.(2010). Istorija na industriskiot dizajn, Mashinski fakultet, Skopje

8. Mursell, J. (2009). Windsor Chairmaking, Hardback, America

9. Hill, J.(1993). Country Chair Making, Hardcover, Lismore, Waterford

10. Crocker, A. (1900). Furniture designing and draughting, Comstock, New York

11. Bertoia, H. (2003). The World of Bertoia, Schiffer Pub Ltd, New York

12. Englund, M (2015). Scandinavian modern, Ryland Peters \& Small, New York

13. Saarinen, E. (2013). Objects and Furniture Design, Ediciones Polígrafa, Washington

14. Destro, F. (2011). Professional Upholste, Grindstone Publishing LLC, United State od America

15. Bast, H. (1946). New Esseentials of upholstery, Milwaukee, New York 
(JPMNT) Journal of Process Management - New Technologies, International Vol. 7, No 1, 2019. 
(JPMNT) Journal of Process Management - New Technologies, International Vol. 6, No 2, 2018. 